\title{
Agronomic Performance of Prunus Clonal Rootstocks under Mid Hill Condition of Himachal Pradesh, India
}

\author{
Ritu Sharma ${ }^{1}$ and Amit Kumar ${ }^{2}$ \\ ${ }^{1}$ Department of Fruit Science, Dr Y S ParmarUniversity of Horticulture and Forestry, \\ Nauni, Solan (HP) 173 230, India \\ ${ }^{2}$ Department of Fruit Science, Faculty of Horticulture, SKUAST-Kashmir, Shalimar, \\ Srinagar $(J \& K) 190$ 025, India \\ *Corresponding author
}

\section{A B S T R A C T}

\section{Keywords \\ Prunus, Clonal rootstocks, \\ Evaluation, Mid- hills}

\section{Article Info}

\section{Accepted:}

12 October 2019

Available Online:

10 November 2019
Performance studies of different clonal rootstocks of Prunus species were undertaken in the Departmental field of Fruit Breeding at Dr YSP UHF, Nauni-Solan (Himachal Pradesh). The experimental plant material was comprised of three clonal rootstocks viz., Myrocal (P. cerasifera), Julior (St. Julien x Pershore) and Jaspi (Methley x P. spinosa) introduced from France and planted in the experimental farms. Observations were recorded on one year old plants on the various growth characters(growth habit, plant height $(\mathrm{m})$, plant spread $(\mathrm{m})$, trunk girth $(\mathrm{mm})$, number of branches per plant), foliage characters (leaf bud burst time, leaf area $\left(\mathrm{cm}^{2}\right)$, leaf shape, time of leaf fall), physiological characters (stomatal density and size $(\mu \mathrm{m})$, chlorophyll content $(\mathrm{mg} / \mathrm{g})$ and cold hardiness. With respect to growth characters plant height $(2.35 \mathrm{~m})$, trunk girth $(27.15 \mathrm{~mm})$, plant spread-NS $(1.23 \mathrm{~m})$, plant spread-EW $(1.19 \mathrm{~m})$ and number of branches per plant $(8.67)$ in Myrocal was significantly higher from those of Julior and Jaspi, however, all the three rootstocks exhibited erect growth habit. Early leaf bud burst and leaf fall was noticed in Julior rootstock i.e. $1^{\text {st }}-2^{\text {nd }}$ week of March and $2^{\text {nd }}-3^{\text {rd }}$ week of November. Maximum stomatal density per microscopic field was recorded in Myrocal (34.29) alongwith maximum stomata length $(27.86 \mu \mathrm{m})$, breadth $(17.09 \mu \mathrm{m})$ and chlorophyll content $(2.91$ $\mathrm{mg} / \mathrm{g}$ ). Leaf shape in all the three clonal rootstocks studied was observed as ovate, obovate and obovate in Myrocal, Julior and Jaspi, respectively. Mean per cent electrolyte leached out was maximum (35.93) in Myrocal followed by 33.89 per cent in Julior and 32.23 per cent in Jaspi which was statistically significant. On the whole, all the three rootstocks survived well and shown optimum growth.

\section{Introduction}

Rootstock plays an important role in deciding the success or failure of orcharding enterprise. The productivity of stone fruits in India is considerably low and one of the major reasons is the lack of locally suited clonal rootstocks. Currently peaches, plums, cherries and apricots are grown on seedling rootstocks of unknown origin and genetic background. 
Seedling stocks unlike clonal rootstocks lack uniformity in growth and development and are also prone to prevailing biotic and abiotic stresses. Rootstocks of clonal origin, on the other hand, influence scion characteristics uniformily to a greater extent besides having other inherent characteristics like tree size control, precocity, disease resistance and better adaptation. Clonal rootstock research has received considerable attention in developed countries of the world and large number of clonally propagated rootstocks has been developed. Considering the above, three genetically improved Prunus clonal rootstocks namely Myrocal (a selection of $P$. cerasifera) developed for plums and apricots, Julior [St. Julien $(P$. insititia) x Pershore $(P$. domestica)] developed for plums and peaches, and Jaspi [Methley ( $P$. salicina) x P. spinosa] developed for peaches and nectarines were introduced from France for commercialization in Himachal Pradesh. Since no rootstock can succeed until its horticultural performance is proven especially with respect to mass multiplication, growth and compatibility with scion cultivars. Therefore, an attempt has been made here to evaluate the above mentioned three Prunus clonal rootstocks for growth characters, foliage and cold hardiness.

\section{Materials and Methods}

\section{Location and experimental site}

The present investigations were carried out in the experimental block of the Department of Fruit Breeding and Genetic Resources, UHF, Nauni, Solan (Himachal Pradesh). Experimental farm is situated at an elevation of 1240 metres above mean sea level and lies between $30^{\circ} 50^{\prime} \mathrm{N}$ latitude and $77.08^{\circ} \mathrm{E}$ longitude. The soil of the experimental land exhibits sandy loam texture. Summer is moderately hot during May-June (31.8$34.8^{\circ} \mathrm{C}$ ) while winter is cold during December-January $\left(2.4-3.7^{\circ} \mathrm{C}\right)$. The average annual temperature ranges from 12.4 to $25.4^{\circ} \mathrm{C}$. The average annual rainfall ranges from $100-130 \mathrm{~cm}$, major portion of which is received during monsoon (July-August). Winter rains are usually of lighter intensity and of shorter durations.

\section{Planting material}

The experimental plant material comprised of 'Jaspi' ([Methley (P. salicina) x P. spinosa ]), Myrocal (P. cerasifera) and Julior [St. Julien $(P$. insititia) $\mathrm{x}$ Pershore $(P$. domestica) clonal rootstock of Prunus species which were introduced from France in the year 2003 and planted in the experimental farm of Department of Fruit Breeding and Genetic Resources at a spacing of $3 \times 3$ meters (m).

\section{Observations recorded and statistical analysis}

Observations were recorded on various growth parameters viz. plant height (m), plant spread $(\mathrm{m})$, trunk girth $(\mathrm{cm})$, branching density, internodal length, growth habit and foliage characters (leaf bud burst time, leaf area $\left(\mathrm{cm}^{2}\right)$, leaf shape were also recorded as per their procedure. Stomatal density and size was calculated as described by Beakbane and Majumdar (1975). For the estimation of chlorophyll content $(\mathrm{mg} / \mathrm{g}$ fresh weight of leaves) the leaf samples were prepared as per the method suggested by (Halfacre et al., 1968) and according to the formula given by Hiscox and Israeeistam (1979). Time of leaf fall was calculated after completion of 75 per cent leaf fall.

The cold hardiness was studied by electrolytic conductance test as suggested by Yadava et al., (1978) and the tissue (dormant scion wood) were subjected to $0^{\circ} \mathrm{C},-5^{\circ} \mathrm{C},-10^{\circ} \mathrm{C}$, $15^{\circ} \mathrm{C}$ and $-20^{\circ} \mathrm{C}$. From the $2^{\text {nd }}, 3^{\text {rd }}$ and $4^{\text {th }}$ internodal regions, small segments of dormant shoots from previous year's growth weighing 
$500 \mathrm{mg}$ were taken for the electrolytic conductance test in the month of December. Segments were put in test tubes containing 15 $\mathrm{ml}$ of distilled water and were frozen in a deep freezer. The temperature was lowered at the rate of $2^{\circ} \mathrm{C}$ per hour to freezing temperature of $-25^{\circ} \mathrm{C}$. Samples were allowed to stay at freezing temperature for at least 4 hours and then thawed for 2-3 hours. Electrolytic conductance of the leachate was measured with a Bornstead conductivity bridge equipped with a dip type $\left(\mathrm{K}=1.0 \mathrm{~cm}^{-1}\right)$ conductivity cell at room temperature. Following this, the samples were killed by heating the test tubes in boiling water for 25 minutes. Killed samples were allowed to leach again and the conductance was recorded with conductivity meter (Elico, India). The values expressed as per cent electrolyte were calculated using the formula:

Per cent electrolyte

Conductivity of unboiled samples

= -------------------------------- x 100

Conductivity of boiled samples

The experiment was laid out in RBD and replicated thrice for each rootstock and ten plants were selected in each replication for taking observations. The data was analysed as suggested by Gomez and Gomez (1984).

\section{Results and Discussion}

\section{Growth Characters}

Significant results were obtained with respect to all the studied growth characters among different clonal rootstocks and presented in Table 1. Observations recorded on growth characters of one year old plants revealed that maximum plant height $(2.35 \mathrm{~m})$, plant spreadNS $(1.23 \mathrm{~m})$, plant spread-EW $(1.19 \mathrm{~m})$, trunk girth $(27.15 \mathrm{~mm})$ and number of branches per plant (8.67) in Myrocal was significantly higher from those of Julior and Jaspi. The corresponding values of above growth characteristics in Jaspi $(1.56 \mathrm{~m}, 0.82 \mathrm{~m}, 0.86$ $\mathrm{m}, 17.45 \mathrm{~m}$ and 4.90 , respectively) and Julior $(1.53 \mathrm{~m}, 0.52 \mathrm{~m}, 0.57 \mathrm{~m}, 14.30 \mathrm{~m}$ and 4.65 , respectively) were at par with each other except for plant spread-NS which differs significantly from each other. All the three rootstocks studied exhibited erect growth habit. Myrocal has been found to be vigorous, Julior the weakest one and Jaspi as intermediate. Renaud et al., (1991) also reported Jaspi as semi-vigorous but Renaud and Canelas (1994) reported Julior as the most vigorous rootstock. Duval (2004) and Iglesias et al., (2004) reported Jaspi as weakest one in comparison to GF677.

\section{Foliage Characters}

Data on different foliage characters of three Prunus clonal rootstocks presented in Table 2 reveals significant differences. Maximum leaf area was recorded in Jaspi $\left(19.02 \mathrm{~cm}^{2}\right)$ which was statistically higher than other clonal rootstocks whereas significant difference was observed for leaf area between Myrocal (13.44 $\mathrm{cm}^{2}$ ) and Julior $\left(16.26 \mathrm{~cm}^{2}\right)$. Significant difference was recorded for stomatal density per microscopic field in Myrocal (34.29), Jaspi (29.71) and Julior (24.14). Maximum stomata length $(27.86 \mu \mathrm{m})$ and breadth $(17.09$ $\mu \mathrm{m})$ was recorded in Myrocal followed by $25.26 \mu \mathrm{m}$ and $16.34 \mu \mathrm{m}$ in Jaspi and $23.77 \mu \mathrm{m}$ and $15.93 \mu \mathrm{m}$ in Julior, respectively. For stomata length, Jaspi was at par with Myrocal and Julior but latter two were significantly different and for stomata breadth no significant difference was recorded among all the three clonal rootstocks. Chlorophyll content in Myrocal (2.91 mg/g), Julior (2.26 $\mathrm{mg} / \mathrm{g})$ and Jaspi $(2.42 \mathrm{mg} / \mathrm{g})$ differed significantly from each other. Leaf shape in all the three clonal rootstocks studied was observed as ovate, obovate and obovate in Myrocal, Julior and Jaspi, respectively. Kaundal and Bindra (1987) reported that 
vigorous peach and almond rootstocks possessed higher stomatal density as compared to dwarf rootstocks. In the present study, Myrocal observed to be vigorous and having high stomatal density also had large stomata size whereas Julior having poor vigour and low stomatal density also had small sized stomata. Present results are similar to those obtained by Guirguis and Khalil (1995). The higher stomatal density may increase photosynthetic activity, thereby resulting in the accumulation of more photosynthates which in turn might be contributing to the increased plant vigour (Miller, 1977). Cappellini et al., (1979) correlated higher stomata density and chlorophyll content with the dwarfness of peach plants.

Data pertaining to time of leaf bud burst and time of leaf fall is presented in Table 3. The time of leaf bud burst was second week of March in Myrocal, first to second week of March in Julior and from second to third week of March in Jaspi.

The time of leaf fall in Myrocal, Julior and Jaspi ranged from fourth week of November to first week of December, second week of November to third week of November and third week of November to fourth week of November, respectively.

\section{Annual growth}

Maximum average annual growth during first two years was observed in Myrocal for plant height $(0.68 \mathrm{~m})$, plant spread in NS $(0.43 \mathrm{~m})$ and in $\mathrm{EW}(0.40 \mathrm{~m})$ directions and trunk girth $(12.85 \mathrm{~mm}$ ) followed by Jaspi as $0.61 \mathrm{~m}, 0.42$ $\mathrm{m}, 0.38 \mathrm{~m}$ and $11.58 \mathrm{~mm}$, respectively. Least average annual growth was observed in Julior for plant height $(0.57 \mathrm{~m})$, plant spread in NS $(0.38 \mathrm{~m})$ and in $\mathrm{EW}(0.37 \mathrm{~m})$ directions and trunk girth $(10.22 \mathrm{~mm})$. However, plant height and plant spread-NS in Jaspi was at par with Myrocal and Julior, but for these characters significant differences were recorded between Myrocal and Julior. Further all the three rootstocks differed significantly for average annual growth in trunk girth, but were at par with respect to plant spread-EW direction.

\section{Cold hardiness}

Data regarding the cold hardiness of three Prunus clonal rootstocks subjected to different temperature regimes is presented in Table 4.

Under the treatment where tissue was subjected to $0^{\circ} \mathrm{C}, 22.11$ per cent electrolyte leached out in Jaspi was minimum and at par with 23.33 per cent in Julior, while maximum of 24.77 per cent in Myrocal differed significantly from that in Jaspi and Julior. Maximum electrolyte leached out was observed in Myrocal (30.12 \%) when subjected to $-5^{\circ} \mathrm{C}$ and found to be statistically at par with Julior $(28.88 \%)$. Minimum electrolyte leached out obtained in Jaspi $(27.07 \%)$ which differed significantly from Myrocal and Julior. Per cent electrolyte leached out at $-10^{\circ} \mathrm{C}$ in Myrocal (35.05), Julior (33.43) and Jaspi (31.94) differed significantly, being maximum in Myrocal followed by Julior and Jaspi. Under the treatment where tissue was subjected to $15^{\circ} \mathrm{C}$, significantly different per cent electrolyte leached out was recorded in Myrocal (40.20), Julior (37.05) and Jaspi (34.81). At $-20^{\circ} \mathrm{C}$ temperature maximum electrolyte leached out was recorded in Myrocal (49.78\%) followed by Julior (46.73 $\%)$ and Jaspi (44.84 \%). The difference in all the three clonal rootstocks for per cent electrolyte leached out was significant. On the whole, mean per cent electrolyte leached out was maximum (35.93) in Myrocal followed by Julior (33.89\%) and Jaspi (32.23\%) which was statistically significant. Early defoliation is considered as an indication of early dormancy which in turn may be indication of cold acclimatization (Williams et al., 1972). 
Table.1 Growth characters of one-year old plants of Prunus clonal rootstocks

\begin{tabular}{|c|c|c|c|c|c|c|}
\hline \multirow{2}{*}{ Rootstocks } & \multirow{2}{*}{$\begin{array}{l}\text { Plant height } \\
\text { (m) }\end{array}$} & \multicolumn{2}{|c|}{ Plant spread (m) } & \multirow{2}{*}{$\begin{array}{l}\text { Trunk } \\
\text { girth } \\
(\mathrm{mm})\end{array}$} & \multirow{2}{*}{$\begin{array}{l}\text { Number } \\
\text { of } \\
\text { branches } \\
\text { per plant }\end{array}$} & \multirow{2}{*}{$\begin{array}{l}\text { Growth } \\
\text { habit }\end{array}$} \\
\hline & & $\begin{array}{l}\text { North- } \\
\text { South } \\
\text { (NS) }\end{array}$ & $\begin{array}{l}\text { East- } \\
\text { West } \\
(\mathrm{EW})\end{array}$ & & & \\
\hline Myrocal (P. cerasifera) & 2.35 & 1.23 & 1.19 & 27.15 & 8.67 & Erect \\
\hline Julior (St. Julien x Pershore) & 1.53 & 0.52 & 0.57 & 14.30 & 4.65 & Erect \\
\hline Jaspi (Methley x P. spinosa) & 1.56 & 0.82 & 0.86 & 17.45 & 4.90 & Erect \\
\hline $\mathrm{CD}_{0.05}$ & 0.34 & 0.12 & 0.30 & 3.40 & 1.22 & \\
\hline
\end{tabular}

Table.2 Foliage characters of one-year old plants of Prunus clonal rootstocks

\begin{tabular}{|c|c|c|c|c|c|c|}
\hline \multirow[t]{2}{*}{ Characters } & \multirow{2}{*}{$\begin{array}{l}\text { Leaf } \\
\text { area } \\
\left(\mathrm{cm}^{2}\right)\end{array}$} & \multirow[t]{2}{*}{ Leaf shape } & \multirow{2}{*}{$\begin{array}{c}\text { Stomatal density } \\
\text { (per microscopic } \\
\text { field) }\end{array}$} & \multicolumn{2}{|c|}{ Stomata size $(\mu \mathrm{m})$} & \multirow{2}{*}{$\begin{array}{c}\text { Chlorophyll } \\
\text { content }(\mathrm{mg} / \mathrm{g})\end{array}$} \\
\hline & & & & Length & Breadth & \\
\hline $\begin{array}{c}\text { Myrocal } \\
\text { (P. cerasifera) }\end{array}$ & 13.44 & Ovate & 34.29 & 27.86 & 17.09 & 2.91 \\
\hline$\underset{\text { Julien x Pershore) }}{\text { Julior }}$ & 16.26 & Obovate & 24.14 & 23.77 & 15.93 & 2.26 \\
\hline $\begin{array}{c}\text { Jaspi } \\
\text { (Methley x P. spinosa) }\end{array}$ & 19.02 & Obovate & 29.71 & 25.26 & 16.34 & 2.42 \\
\hline $\mathrm{CD}_{0.05}$ & 3.14 & & 1.74 & 3.55 & 1.74 & 0.10 \\
\hline
\end{tabular}

Table.3 Time of leaf bud burst and time of leaf fall of one year old plants of Prunus clonal rootstocks

\begin{tabular}{|c|c|c|}
\hline $\begin{array}{l}\text { Characters } \\
\text { Rootstocks }\end{array}$ & Time of leaf bud burst & Time of leaf fall \\
\hline $\begin{array}{c}\text { Myrocal } \\
\text { (P. cerasifera) }\end{array}$ & $2^{\text {nd }}$ week of March & $\begin{array}{c}4^{\text {th }} \text { wk November to } 1^{\text {st }} \text { wk } \\
\text { December }\end{array}$ \\
\hline $\begin{array}{c}\text { Julior } \\
\text { (St. Julien x Pershore) }\end{array}$ & $1^{\text {st }}$ to $2^{\text {nd }}$ week March & $2^{\text {nd }}$ to $3^{\text {rd }}$ wk November \\
\hline $\begin{array}{c}\text { Jaspi } \\
(\text { Methley } \times \text { P. spinosa) }\end{array}$ & $2^{\text {nd }}$ to $3^{\text {rd }}$ week March & $3^{\text {rd }}$ to $4^{\text {th }}$ wk November \\
\hline
\end{tabular}

Table.4 Cold hardiness determined by electrolyte conductance test in Prunus clonal rootstocks

\begin{tabular}{|c|c|c|c|c|c|}
\hline \multirow{2}{*}{ Rootstock } & \multicolumn{5}{|c|}{ Electrolyte leachate (\%) at different temperature regimes $\left({ }^{\mathbf{0}} \mathbf{C}\right)$} \\
\cline { 2 - 6 } & 0 & -5 & -10 & -15 & -20 \\
\hline $\begin{array}{c}\text { Myrocal } \\
\text { (P. cerasifera) }\end{array}$ & 24.77 & 30.12 & 35.05 & 40.20 & 49.78 \\
\hline $\begin{array}{c}\text { Julior } \\
\text { (St. Julien x Pershore) }\end{array}$ & 23.33 & 28.88 & 33.43 & 37.05 & 46.73 \\
\hline $\begin{array}{c}\text { Jaspi } \\
\text { (Methley } \mathbf{P} \text {. spinosa) }\end{array}$ & 22.11 & 27.07 & 31.94 & 34.81 & 44.84 \\
\hline $\mathbf{C D}_{\mathbf{0 . 0 5}}$ & & & & & \\
\hline Treatment & 0.63 & & & \\
\hline Rootstock & 0.82 & & & \\
\hline Treatment x Rootstock & 1.40 & & & \\
\hline
\end{tabular}


Myrocal recording maximum electrolyte leaching in the present investigations also shed its leaves very late as compared to early leaf shedding in Jaspi and Julior recording less electrolyte leaching, indicating reduced cold hardiness of Myrocal as compared to Julior and Jaspi.

From the present study it is clear that all the three Prunus rootstocks namely Myrocal, Julior and Jaspi have survived well and shown optimum growth under mid hill conditions of Himachal Pradesh. Though vigorous growth has been recorded in Myrocal, the other two rootstocks Julior and Jaspi appears to be less vigorous and more cold hardy.

\section{References}

Beakbane, A.and Majumdar, P.K. 1975. A relationship between stomatal density and growth potential in apple. Journal of Horticultural Science, 50: 285-289.

Cappellini, P., Della Strada, G., Fideghelli, C. and Quarta, R. 1979. Parametrimorfosiologici di selezioninane di pesco. Annali Instituto de la Sperimentale Frutticoltura, 10: 19-24.

Duval, H. 2004. Agronomic evaluation of INRA Prunus rootstocks for two Japanese plum cultivars: 'Friar' and 'Black Amber'. Acta Horticulturae, 663: 957-960.

Renaud, R. and Canelas, M. 1994. The effect of the rootstock on various morphological traits of the variety $(P$. domestica). Acta Horticulturae, 359: 225-228.

Gomez, K.A. and Gomez, A.A. 1984. Statistical Procedures for Agricultural Research. John Wiley and Sons, New York, 680p.

Guirguis, N.S. and Khalil, M.A. 1995. Leaf stomata and stem lenticels as a means of identification of some stone fruit stocks. ActaHorticulturae, 409: 229233.

Halfacre, R.G., Baraden, J.A. and Rollens, H.A. Jr. 1968. Effect of Alar on morphology, chlorophyll content and net $\mathrm{CO}_{2}$ assimilation rate of young apple trees. Proceedings of the American Society for Horticultural Science, 93: 40-52.

Hiscox, J.D. and Israeeistam, G.F. 1979. A method for extraction of chlorophyll from leaf tissue without maceration. Canadian Journal of Botany, 57: 13321334.

Iglesias, I., Montserrat, R., Carbo, J., Bonany, J. and Casals, M. 2004. Evaluation of agronomical performance of several peach rootstocks in Lleida and Girona (Catalonia, Ne-Spain) Acta Horticulturae, 658: 341-348.

Kaundal, G.S. and Bindra, A.S. 1987. Variability studies on stomatal counts and growth potential in peach and almond rootstocks. Journal of Research PAU, 24(4): 601-606.

Miller, E.C. 1977. Stomatal distribution as an index for predicting vigour of plum rootstocks. Indian Journal of Horticulture, 34(2): 117-119.

Renaud, R., Salesses, G., Roy, M. and Bonnet, A. 1991. Development and selection of new rootstocks of Prunusdomestica. Acta Horticulturae, 283: 253-259

Williams, B.J., Pellett, N.E. and Klein, R.M. 1972. Phytochrome control of growth cessation and initiation of cold acclimation in selected woody plants.Plant Physiology,50: 262-265.

Yadava, U.L. and Doud, S.L. 1978. Effect of peach seedling rootstocks and orchard sites on cold hardiness and survival of Peach. Journal of American Society for Horticultural Science, 103(3): 321323. 


\section{How to cite this article:}

Ritu Sharma and Amit Kumar. 2019. Agronomic Performance of Prunus Clonal Rootstocks under Mid Hill Condition of Himachal Pradesh. Int.J.Curr.Microbiol.App.Sci. 8(11): 13641370. doi: https://doi.org/10.20546/ijcmas.2019.811.159 